\title{
GENDER BIAS AS REFLECTED ON Upin \& Ipin THE SERIES
}

Bias Gender dalam Serial Upin \& Ipin

\author{
Herry Nur Hidayat ${ }^{a}$, Wasana ${ }^{b}$
}

a,bFakultas Ilmu Budaya Universitas Andalas Padang

Pos-el: herrynh@,hum.unand.ac.id ${ }^{\mathrm{a}}$, wasana@hum.unand.ac.id ${ }^{\mathrm{b}}$

\section{Naskah diterima: 10 Agustus 2019; direvisi: 6 Desember 2019; disetujui: 7 Desember 2019}

DOI: $10.26499 /$ jentera.v8i2.1642

\begin{abstract}
Abstrak: Artikel ini memaparkan hasil penelitian terhadap serial animasi Upin $\mathcal{E}$ Ipin yang memperlihatkan bias gender dalam beberapa episodenya. Sebagai salah satu bentuk media yang kemudian menjadi media pembelajaran seharusnya bisa berposisi netral dalam hal gender. Penelitian ini menggunakan metode penelitian kualitatif. Objek material diamati secara berulang untuk memperoleh indikator yang menunjukkan bias gender yang kemudian dianalisis dalam kerangka sosiologi dan perspektif feminisme. Hasil penelitian menunjukkan muatan bias gender dalam Upin E Ipin terdapat dalam tokoh dan penokohan serta pembentukan latar. Dalam tokoh dan penokohan serial animasi ini, melalui dialog dan lakuannya, terdapat kecenderungan "kepemilikkan" warna dan benda tertentu. Dalam hal ini, warna merah muda dianggap sebagai warna "milik" perempuan. Di samping itu, terdapat pula kecenderungan sifat dan perilaku perempuan dan laki-laki. Perempuan harus memiliki sifat lembut dan rapi sementara laki-laki harus keras dan berani. Dalam latar cerita, muatan bias gender muncul sebagai bentuk wilayah dominasi perempuan dan lakilaki. Perempuan dibatasi dalam wilayah domestik rumah tangga sementara laki-laki berada di wilayah luar (publik).
\end{abstract}

Kata-kata kunci: Upin \& Ipin, bias gender, feminisme, televisi

Abstract: This paper describes gender bias as reflected in Upin \& Ipin the series. This study employed qualitative research methods in which the objects were observed repeatedly to construct indicators that reflected gender bias. Then it was followed by analyzing them within sociological and feminist perspectives. It showed that there was an imbalance in gender position within several episodes of Upin \& Ipin. As one of the media forms that later on becoming an instructional media, it should posit its position neutrally in the term of gender issues. The content of the gender bias in Upin \& Ipin reflected within characters and settings. It reflected as the characters articulate their dialogues and behave in their daily life. There was a tendency to determine the ownership of boys and girls based on colors and things. In this case, pink regarded as to belong to girls. Also, there was a tendency to describe that girls and boys behave differently. For example, girls should be gentle and neat, and boys should be strong and brave. In the term of setting, gender bias reflected in the domination of areas that boys dominate outdoor public space while girls are in the domestic sector (households).

Keywords: Upin $\mathcal{E}$ Ipin, gender bias, feminism, television 
How to Cite: Hidayat, Herry Nur, Wasana. (2019). Gender Bias as Reflected on Upin \& Ipin The

Series. Jentera: Jurnal Kajian Sastra, 8 (2), 113-129. (https://doi.org/10.26499/jentera.v8i2.1642)

\section{INTRODUCTION}

Since Upin \& Ipin the series released in 2007, the animated series has become an exciting phenomenon in electronic media. Nizam Abdul Razak, Safwan Abdul Karim, and Osama Zaid initiated the film production house named Les' Copaque in Malaysia. At first, the series was created to welcome Ramadhan 2007 and aired on TV9 Malaysia. The contents of the latter series were not only the teachings about Islam, but also on ethics, manners, awareness of differences, and children creativity (Arlena and Kurniasari, 2013a; Bawono and Haryanto, 2017).

As art production, the series is very successful - the animation series aired by several televisions outside Malaysia, including Indonesia. Moreover, since 2008, the series is aired by Disney Chanel Asia, which has networks in some countries, namely Malaysia, Singapore, Indonesia, Brunei, Thailand, Philippines, Vietnam, Cambodia, Hong Kong, and South Korea. Disney Chanel is one of the television networks that broadcast special children's shows. In this case, it shows the success of the series as instructional media for children.

Nowadays, television and film for the community are not only regarded as an information and entertainment media. Currently, a video has also become a vehicle for the most effective learning (Sexton, Gervasoni, and Brandenburg, 2009). Children and even adults tend to imitate what they have seen on television. The emergence of violence cases and crimes are ordinary due to television shows and movies (Almeida, del Barrio, Marques, Gutiérrez, and van der Meulen, 2001; Blumberg, Bierwirth, and Schwartz, 2008; Kirsh, 2006; Peters and Blumberg, 2002). Therefore, the role of the audience is also vital to select the appropriate content from television shows. Society cannot rely only on the censorship institution and consumers' foundations that are not comparable to various kinds of television shows.

Audiences are required to be aware to receive and to respond to television broadcasts. Being smart becomes essential, especially when it deals with children. Many people (in Indonesia) consider animation /cartoon films are for kids, which is a wrong assumption. There are many animation and cartoon films are not suitable 
for children. In this situation, parents' roles are essential to be more active and wise in accompanying their children when watching television (Aditama, 2018; Juliswara, 2014; Karima and Christin, 2015).

On the other hand, children's TV shows sometimes assumed to contain negative instructions; for example, the content is about the gender issue (Lavery, 2013; Thompson and Zerbinos, 1997). Some television programs (especially for children) contain gender bias. Sometimes the tendency of showing the maleness is highlighted in those TV shows. Besides, the absolute belonging is on the men's side that this is also frequently appeared.

Sexually, humans are made up of males and females. However, gender does not determine one's social status (Eckert and McConnell-Ginet, 2003; Ferrebe et al., 2012; Trier-Bieniek and Leavy, 2014). People should not be limited to masculinity and femininity in their activities. Conscious or unconscious, gender differences are built socially by particular communities. However, the Upin \& Ipin animated series appears to contain fairly thick gender-biased content. This matter is shown in several episodes, which pointed out that "it" belongs to women, and "this" is the property of men. Besides, that matter also indicated that women have "property rights" to specific colors and games. Psychologically (Burr, 2002; Islam and Asadullah, 2018), this differentiation will affect the psychological development of children. In the end, it will affect the social behavior of the child until adulthood.

Based on the background above, this paper tries to answer the question of what forms of gender bias in the Upin \& Ipin series. In this case, solving the problem will be limited to the imposition of dialogue and character.

\section{LITERATURE REVIEW}

British sociologist Ann Oakley introduced the gender concept. She distinguishes between gender and sex. Sex differences mean the difference based on biological characteristics, namely concerning procreation (menstruation, pregnancy, childbirth, and breastfeeding). Gender differences are symbolic or social differences that stem from differences in sex, but not always identical with it. Sex is the biologically determined differences between men and women, while gender 
refers to the cultural differences, the product of social conditioning. This distinction was critical in reconsidering women writers who had traditionally viewed as usurpers in the "male" domain of creativity. So, gender is more directed to social symbols given in society (Daulay, 2007; Lai and Cooper, 2016; Quinn, 2006; TrierBieniek and Leavy, 2014)

Gender bias is a social product in male dominance. According to Sofia (Sofia, 2003), the determinants of gender inequality include (1) long-standing problem, (2) gender values embraced by society, (3) values and gender roles found in textbooks, (4) the value of gender instilled by teachers and (5) gender-bias policies.

Gender role determines by a series of factors which are socialized and constructed to the socio-cultural background. This belief then strengthens by myth and religion, where finally, gender feels like God's destiny. Therefore, a general understanding of what is gender is needed to open society's perception that gender role is not God's will, but it is social construction that formed through a long historical process (Darni and Abida, 2017; Zaduqisti, 2009). As a social construction, gender differences have given rise to injustice, especially for women, which is generally in the form of marginalization, stereotyping, violence, and workload (Herawati, 2017; Rosita, 2017). According to traditional concepts, women must be submissive, obedient, and loyal to their husbands. Through this patriarchal system, the difference in position between women and men became obvious in the status and power in the society (Suryani, 2017).

Recent work on gender has demonstrated how it inscribed on and reproduced through the body. Gender has no ontological reality; it is an effect of codes of performance which endlessly and compulsively repeated within the hegemonic framework of "compulsory heterosexuality." Gender is, in fact, a product of endless incitements which serve to maintain the appearance of "difference." However, despite their theoretical importance, they are mostly abstract and fail to examine how gender is performed and reproduced at the mundane level of everyday social and cultural practices (Entwistle, 2004).

Gender bias in Indonesia is one of the issues that have been handed down. On the other hand, the public view of discouraging women has also rooted. Women 
considered a mere appendage of domestic life (Rahminawati, 2001; Sakina and A, 2017).

In the field of education, gender bias is obvious from teaching materials. The phrase "Mother is cooking in the kitchen" and "Dad is working at the office" indirectly instill gender bias to the students. Teacher instruction is also still shown in gender bias. Still widely seen, boys were given a toy car or a pistol while the girls were given a doll or playhouse. Gender is a division of roles, behaviors, men and women manners by culture/society through the interpretation of the biological differences of men and women (Abraham, 2016; Ferrebe et al., 2012). So, gender not obtained from birth but is known through the learning process (socialization) from childhood to adulthood (Eagly, Beall, and Sternberg, 2004; Ferrebe et al., 2012). Therefore, gender can be adjusted and changed.

In addition to using the sociological theory of literature, this study also uses a feminist perspective. The feminist perspective in this research is looking at how far the dominance of men over women with attention to traditional concepts that praise women. This study focus on women's position and underdevelopment of women from men in all aspects of life (Abraham, 2016; Asmarany, 2007; Chin, 2018; Endraswara, 2003). The goal is to balance feminist and gender interrelations, reject everything that marginalized, subordinated, and demeaned by the dominant culture. Feminists reject injustice as a result of patriarchal society, centered on men. In terms of literature, feminist literary criticism aims to dismantle and deconstruct the assessment system in general, which is always in terms of men understanding (Burr, 2002; Ferrebe et al., 2012; Selden, 1985). Finally, a general limitation in this study is the concept of Culler (Culler, 1983) 'reading as a woman.' What meant here is the awareness of the existence of essential differences in the sexes about social life and culture.

On the other hand, there are some studies on Upin \& Ipin The Series. Fahlevi (2017) states that Upin \& Ipin affect children's communication behavior as a second language. Anggraeni (2010), Basirudin (2010), Pri'ambudi (2011), Purnomo (2016), Rahmad (2015), and Untari and Purnomo, (2016) claim that Upin $\&$ Ipin has a strong moral and religious education content, which are religious, honest, tolerance, discipline, friendly, hard work, responsibility, creative, curiosity, 
appreciate the achievements, social care / care about others, brave, cooperation, wisdom, respect for all life forms and environment that care of each other, respect for others / public politeness, mutual help, and self-respect. Arini (2011) and Mustanzier (2016) claim that Upin \& Ipin use denotative words so viewers can easily capture the meaning. Meanwhile, Nadzri and Hassan (2013), Arlena and Kurniasari (2013), Saputro (2011), states that Upin \& Ipin shows Malay and Islamic identity. Upin \& Ipin animation series that portrayed people from different ethnic groups interacting with each other. The characters in the animation use different particles in representing their ethnicity. Besides that, a typical Malaysian speech pattern of the particle 'lah' is found to be widely used by all Malaysians, regardless of their ethnic group.

\section{METHOD}

This study used qualitative methods, which are more focused on the interpretation. Meanwhile, the approach used in the study is an objective approach which used to find the elements that build up objects as a form of structure. In this approach, the object analyzed through a process of observation and repeated readings. The approach is expected to be able to acquire indicators that can use in the next stage of interpretation.

This study used a series of literature study. The research literature is searching for data in the form of archives and various articles that touched on matters relating to this study. The results of the literature research used as additional data. The data are interpreted in the framework of feminist perspective.

The objects of this study were 61 episodes of the series Upin \& Ipin and Upin \& Ipin dan Kawan-Kawan in season 3, 4, 5, and 6. This object then sorted and selected to obtain the appropriate data for this study in terms of compliance with the approaches and theories used in this study, namely gender bias.

\section{RESULT AND DISCUSSION}

\section{Upin \& Ipin: Entertainment and Learning Media}

Television footage has evolved. The mainstay program of a television program is no longer news. The entertainment and children program has also 
become the television flagship. As television stations compete to attract viewers, including children. Cartoons are the one that is shown in the hope to be children favorite. The cartoon shows considered to be an appropriate show for children.

Cartoon programs for children should contain education. Among them, the children can learn and aware of the environment and educational content materials about various things. Ausekle and Šteinberga (2011) state that animation in literature lessons improves learners' intellectual, emotional, and social experiences. Participants in the animation making process can promote their creativity and knowledge in collaboration with each other in the value-oriented learning process.

However, in 2007, when Upin \& Ipin appeared on television, many of the comments directed at it. Upin \& Ipin considered being the best for kids because it contains many learning materials (Pri'ambudi, 2011; Purnomo, 2016; Rahmad, 2015). At the first appearance, Upin \& Ipin display Ramadhan setting and considered to teach children Islamic material mainly worship during Ramadhan.

A year later, Upin \& Ipin come up with Upin \& Ipin Setahun Kemudian. Still hiring more about Ramadan, Upin \& Ipin had become a favorite not only children but also adults. Furthermore, until now, Upin \& Ipin has reached eight seasons with not less than 100 episodes.

Apart from comments that Upin \& Ipin contain Malaysian government propaganda, it must be recognized that these series mount educational materials for children through the child's perspective (Hardika, 2018). Not many television programs used this perspective. For example, the animated film Adit Sopo and Jarwo are deemed to contain children's education, but the viewpoints are not the children's perspective. Problems and conflicts are displayed nor in the levels of children (Ulya, 2016).

That is the differentiation between Upin \& Ipin compared with another animation program. Upin \& Ipin lift events experienced by children. Problems and conflicts resolved within the limits of a child's acceptance and perspective. Characters in Upin \& Ipin constructed under the children's personality. Even the voices, the dubbers, in Upin \& Ipin also dominated by children. Likely, children find themselves on TV. In Upin \& Ipin, each character has a unique characterization. Audiences can easily recognize the figures only through the voice 
and speaking style or acting in the story (Putri, 2018). Besides loaded with learning materials, nationalism, respect for a national hero, and solidarity, the most important is the sense of unity shown in characters that appear from the various tribes and different backgrounds (Arlena and Kurniasari, 2013b; Nadzri and Hassan, 2013; Saputro, 2011).

However, some contents should not appear in this series. The content is gender bias. The child should be given the freedom to choose the preferences or interests. Environmental influences that affect views on gender will make the child may have been deemed superior to a particular gender (Fine and Rush, 2018).

\section{Gender Bias in Upin \& Ipin}

Noted previously, Upin \& Ipin series loaded with learning and education content for children. However, in some episodes, Upin \& Ipin contain gender bias, which is inappropriate in a children's program.

Gender is a division of roles, behavior, men, and women's manners by culture or because they influence the community through the interpretation of the biological differences of men and women. Therefore, gender is not acquired at birth but is known through the learning process (socialization) from childhood to adulthood (Daulay, 2007). Thus, the core problem of gender is differentiation.

Although related, gender and sex are different in a social context. Sex-related to the human nature of men and women. In this case, women have menstruation periods, pregnancy, childbirth, and breastfeeding. However, if it considers that the men are stronger than women, women are holding the domestic sector, women have to apply smooth and soft, and they are gender differentiation. A patriarchal community forms it.

This gender bias, intentionally or not, has been imparted to children through the medium of both formal and non-formal learning processes. In formal schooling, teachers tend to give an example of "Dad works" and "Mother cooking " or "Father hoeing" and "Mom wash." While in the non-formal education of parents tend to distinguish children through dolls for girls and cars or robots for boys (Thompson and Zerbinos, 1997). It shows the non-neutrality of gender in the learning process. Here is the exposure of gender bias in the Upin \& Ipin series. 
The gender bias that emerges through the characters in this series obtained through dialogue and imposition figures. Dialogue and the imposition are both male and female characters. In Upin \& Ipin season 1 episode 7, there is a dialogue between Mei Mei and Ehsan that show gender bias.

Mei Mei : Ini macam main pun adakah?

Ehsan : Ada lah, kau orang perempuan mana tahu?

Mei Mei : Is there any kind of this play?

Ehsan : Of course, what you women know?

The dialogue was in the event when the children were playing games spider beauty. At that time, Mei Mei thought the match was compliant until one of them dies. However, the match was a beauty contest.

The dialogue is not directly showing the audience the differences between women with men on knowledge of something. A game usually done by boys and girls are not worth getting to know and find out.

In the "Sayang Kak Ros" episode, there is a dialogue that shows the propensity of ownership of color for women.

Ipin $\quad$ : Ipin nak warna merah jambu.

Upin : Eh, itu warna perempuan lah.

Ipin : Ipin choose pink color.

Upin : Eh, that is the women color.

The dialogue contained in the current events Upin \& Ipin wants to buy new clothes for the feast. In the event, it also stated a reason that the pink color used by Kak Ros. This event suggests that a habit that experienced by the child, in this case, Upin \& Ipin, could be a truth for them. Pink is color usually used by women, which are considered owned by women.

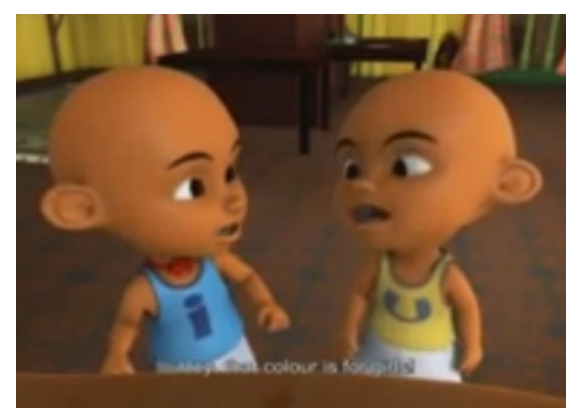




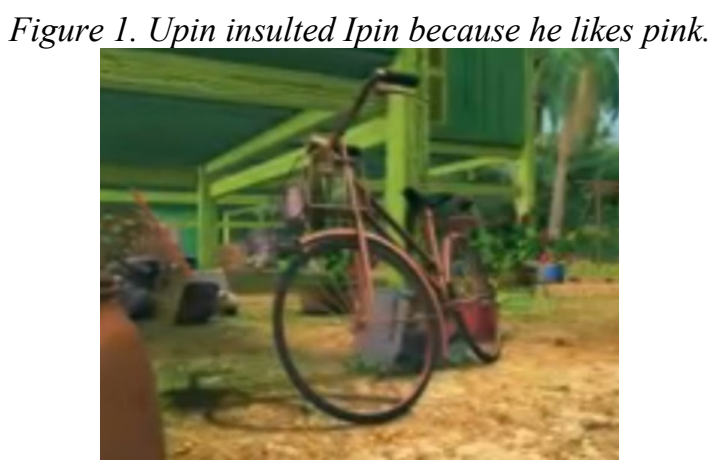

Figure 2. Kak Ros' bicycle.

In the "Basikal Baru" episode also appeared tendencies ownership of objects, in this case, a bicycle (bike).

$$
\begin{array}{ll}
\text { Ehsan } & \text { : Eh, itu kan basikal perempuan? } \\
\text { Fizi } & \text { :Betul itu, malu lah. } \\
\text { Ehsan } & : \text { Uh, that's women's bike? } \\
\text { Fizi } & : \text { Yes it is, it's a shame. }
\end{array}
$$

The dialog tells when Upin \& Ipin want to play the bike with his friends. At that time, Upin \& Ipin, who do not have a bike as other friends pointed to the bike belong to Kak Ros. Spontaneously, Ehsan said that the bike is a woman bicycle, and also Fizi said that it would be embarrassing if Upin \& Ipin as a boy using that bike.

Those three events above imply sex-based ownership, which is a game that is improperly played by girls, colors that are not suitable for use by boys, and bikes that are only suitable for girls and suggests that a habit that experienced by the child, in this case, Upin \& Ipin, could be a truth for them.

In the same episode ("Basikal Baru "), Mail dialog appears that shows the ideal characteristics of a boy.

\author{
Ipin : Tak sakit ke? \\ Mail: Ini lah anakjantan. Tahan sakit. \\ Ipin : Is that hurt? \\ Mail: I am a strong boy. Of course not.
}

The dialog above happens when Mail shows the scars because he falls when he rides his father's bicycles. Because of that big and tall bike, Mail repeatedly falls 
and hurts shown by many scars on his body. These events indicate that the boy should be strong. Males interpreted as dashing and daring. In this event, Mail told that boy should be dashing, daring, durable, and not give up easily. However, in reality, the image of masculinity is not the same in every region. Astutiningsih (Astutiningsih, 2013) states, discussion about the masculine body will never produce uniformity of ideal body concepts. The concept is very ambiguous because of its dependence on various background contexts, whether cultural, social, or historical.

Besides appears in dialogues, gender bias also shown in the characters' actions. In the episode "Air Kolah Air Laut," Upin \& Ipin playing water in the bathtub. They imagine that they were in the middle of the seas as admiral. In Upin \& Ipin imagination, Mei Mei is a princess who must be rescued from pirates (Figure $3)$.

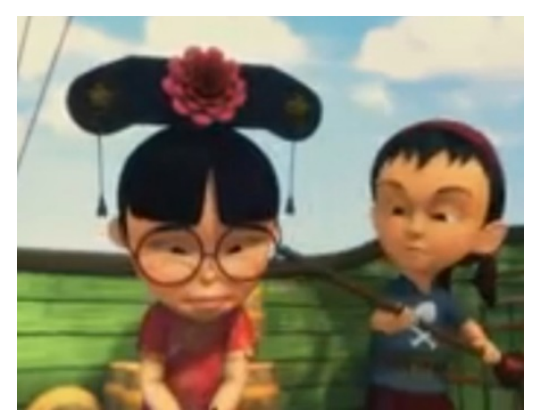

Figure 3. Mei Mei, as a princess.

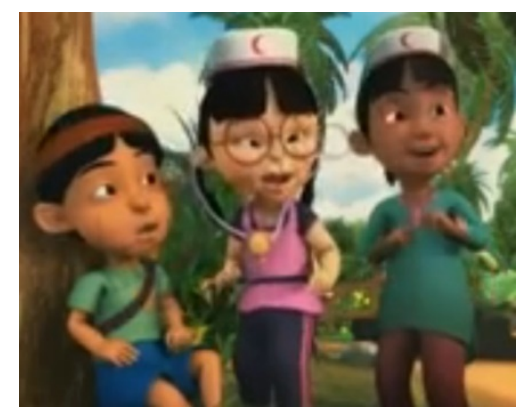

Figure 4. Mei Mei and Devi as nurse.

Also, in the "Kami 1 Malaysia" episode, when playing war, girls play as nurses and boys as soldiers. This episode shows tendencies the personality either by girls and boys must-have. Girls must possess compassion and soft compared to boys. In contrast, boys are required to have a hard and courageous nature. 
In some episodes, girl characters in Upin \& Ipin identified with the ability to cook. Mei Mei always invites his friends to play cooking. Also, she always plays cooking with her school friend, Devi.

The picture above (Figure 4) is from the "Kami 1 Malaysia" episode. To Mail, Mei Mei told him that she always plays together with Devi.

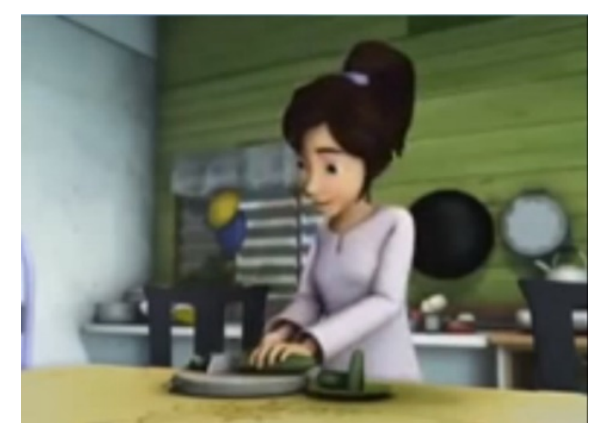

Figure 5. Kak Ros, cooking in the kitchen.

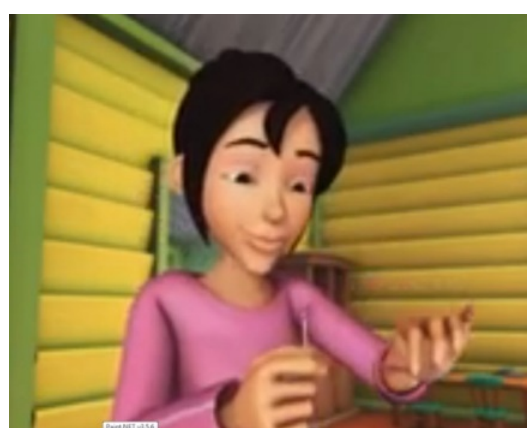

Figure 6. Kak Ros, sewing.

In other events, Kak Ros is always shown as someone who always takes care of the house. Besides cooking in the kitchen, Kak Ros also has shown sew and wash clothes (Figure 5-8).

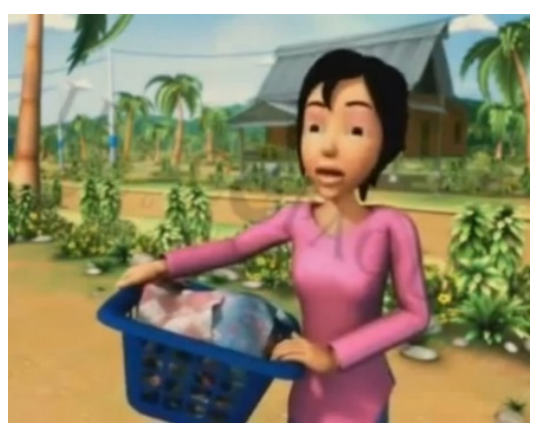

Figure 7. Kak Ros, with clothes. 


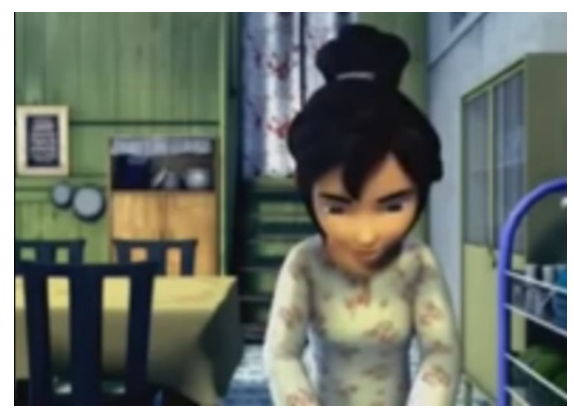

Figure 8. Kak Ros, in the kitchen

Description of the characterizations above shows the tendency of gender imbalance in Upin \& Ipin series. Boy characters build into hard figures, bold, and play outside the house with more risk. Meanwhile, girls build as soft, polite, and play with little risky game.

Besides the characterizations, gender bias in the Upin \& Ipin series also emerges through the settings. However, the setting still related to characters and characterizations.

Female characters in this series frequently appear in the room or house. For example, many events show that Kak Ros is in the house, kitchen, her room, or family room. Just a few events show this character outside the house. In contrast, boys often displayed outside the house. Upin, Ipin, and friends are always playing outside rather than inside the house (Figure 9).

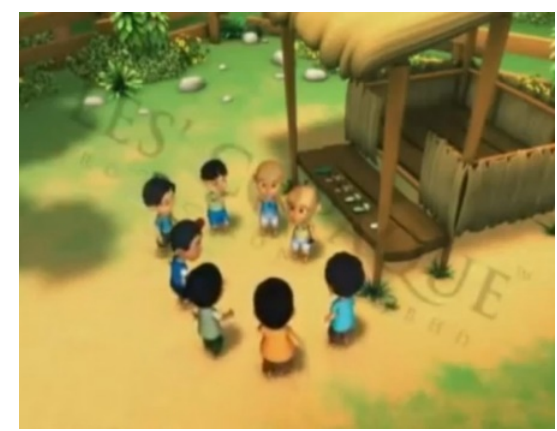

Figure 9. Boys, playing outside.

The descriptions above indicate Upin \& Ipin series conceive gender bias that represents the work area for women and men. Public and domestic spheres are one of the contexts of this gender bias. Women are considered a limited role in the private area (households), while men have a greater area, which is the public domain. 


\section{CONCLUSION}

It has mentioned above that gender bias is sociological matters. Gender bias is a distinction based on the assumption that gender shaped by social and cultural. Research on the Upin \& Ipin series indicates that gender bias still exist in the entertainment media. Consciously or not, producers admit this gender bias in consideration of normal and acceptable things to the public (consumers).

The results refer to gender bias that can mount in some ways and forms. Gender bias contents in the Upin \& Ipin series are indicated by character and characterization and act as well as the establishment of the setting.

Furthermore, the charge of gender bias in the Upin \& Ipin appears in terms of ownership of specific colors and objects, in this case, a pink and shaped bike, which considered "owned" by women. Attitude, character, and behavior of women and men also appear in this animated series. Men are considered to be having a hard and courageous nature, while women should have a soft nature and tidy.

Also, the setting shows gender bias charges. Boy characters displayed more often outside the house. In contrast, girl and women characters appear inside the room with the duties and housework. Learning media should avoid gender bias contents. Children naturally develop their own choices. It does not mean it allows deviating from nature; it gives a breadth of knowledge on the environment.

\section{BIBLIOGRAPHY}

Abraham, A. (2016). Gender and creativity: an overview of psychological and neuroscientific literature. Brain Imaging and Behavior, 10, 609-618. https://doi.org/10.1007/s11682-015-9410-8

Aditama, R. W. (2018). Analisis Isi Kekerasan dalam Film Animasi Serial The Simpsons. Jurnal E-Komunikasi, 6(1), 1-9.

Almeida, A., del Barrio, C., Marques, M. M., Gutiérrez, H., and van der Meulen, K. (2001). A script-cartoon narrative of bullying in children and adolescents. In Prevention and Control of Aggression and the Impact on its Victims (hal. 161-168). Boston, MA: Springer US. https://doi.org/10.1007/978-1-47576238-9_19

Anggraeni, $\overline{\mathrm{W}}$. H. (2010). PESAN MORAL PADA FILM ANIMASI UPIN DAN IPIN (STUDI SEMIOTIKA PADA FILM LAYAR LEBAR ANIMASI UPIN DAN IPIN

" Geng Upin Dan Ipin Petualangan bermula"). Surabaya.

Arini, N. M. (2011). PEMAKAIAN BAHASA DALAM FILM KARTUN ANAK UPIN DAN IPIN : ANALISIS DIKSI. Surabaya.

Arlena, W. M., and Kurniasari, N. G. A. K. (2013a). Malays, China and Indian Ethnicities: A Case Study of Art and Ethnography Content Analysis and 
Multiculturalism on Upin-Ipin Animation. Jurnal Komunikasi ASPIKOM, 2(1), 629. https://doi.org/10.24329/aspikom.v2i1.41

Arlena, W. M., and Kurniasari, N. G. A. K. (2013b). Malays, China and Indian Ethnicities: A Case Study of Art and Ethnography Content Analysis and Multiculturalism on Upin-Ipin Animation. Jurnal ASPIKOM, 2(1), 629. https://doi.org/10.24329/aspikom.v2i1.41

Asmarany, A. I. (2007). Bias Gender Sebagai Prediktor Kekerasan Dalam Rumah Tangga. Jurnal Psikologi, 35(1), 1-20.

Astutiningsih, I. (2013). Laki-Laki "Cantik" di Mata Perempuan: Konstruksi Tubuh Superhero dalam Sastra Cyber. JENTERA: Jurnal Kajian Sastra, 2(2), 53-61. Diambil dari https://ojs.badanbahasa.kemdikbud.go.id/jurnal/index.php/jentera/article/vie $\mathrm{w} / 408 / 200$

Ausekle, D., and Šteinberga, L. (2011). ANIMATION AND EDUCATION: USING ANIMATION IN LITERATURE LESSONS. Pedagogy Studies / Pedagogika, (104), 109-114.

Basirudin. (2010). NILAI-NILAI MORAL DALAM FILM SERIAL KARTUN UPIN DAN IPIN. Purwokerto.

Bawono, G. A., and Haryanto, D. (2017). Pesan Moral dalam Serial Kartun Animasi Upin dan Ipin Episode “ Istimewa Hari Ibu .” Layar, 4(1), 33-46.

Blumberg, F. C., Bierwirth, K. P., and Schwartz, A. J. (2008). Does Cartoon Violence Beget Aggressive Behavior in Real Life? An Opposing View. Early Childhood Education Journal, 36(2), 101-104. https://doi.org/10.1007/s10643-008-0280-1

Burr, V. (2002). Gender and Social Psychology. New York: Routledge.

Chin, G. V. S. (2018). The Southeast Asian Woman Writes Back: Gender, Identity and Nation in the Literatures of Brunei Darussalam, Malaysia, Singapore, Indonesia and the Philippines. (G. V. S. Chin and K. M. Daud, Ed.). Singapore: Springer. Diambil dari http://ias.ubd.edu.

Culler, J. (1983). On Deconstruction. London: Routledge and Kegan Paul.

Darni, and Abida, F. I. N. (2017). Gender Bias in Elementary School Language Textbooks. International Journal of Gender and Women's Studies, 5(1), 128133. https://doi.org/10.15640/ijgws.v5n1p13

Daulay, H. (2007). Perempuan dalam Kemelut Gender. Medan: USU Press.

Eagly, A. H., Beall, A. E., and Sternberg, R. J. (2004). The Psychology of Gender. New York - London: The Guilford Press.

Eckert, P., and McConnell-Ginet, S. (2003). Language and Gender. Cambridge, New York, Melbourne, Madrid, Cape Town, Singapore, São Paulo Cambridge: Cambridge University Press.

Endraswara, S. (2003). Metode Penelitian Sastra: Epistemologi, Model, Teori, dan Aplikasi. Yogyakarta: FBS UNY.

Entwistle, J. (2004). From Catwalk to Catalog: Male Fashion Models, Masculinity, and Identity. In H. Thomas and J. Ahmed (Ed.), Cultural Bodies Ethnography and Theory. Victoria: Blackwell Publishing.

Ferrebe, A., Tolan, F., Andermahr, S., Naylor, A. K., Bates, C., Baker, B., ... Ballaster, R. (2012). Teaching Gender. (A. Ferrebe and F. Tolan, Ed.), Teaching Gender. New York - Hampshire: PALGRAVE MACMILLAN.

Fine, C., and Rush, E. (2018). "“Why Does all the Girls have to Buy Pink Stuff?”, 
The Ethics and Science of the Gendered Toy Marketing Debate. Journal of Business Ethics, 149(4), 769-784. https://doi.org/10.1007/s10551-016-30803

Gender and Child Development. (1994). International Conference on Population and Development. Washington DC: Pan America Health Organization.

Hardika, B. B. (2018). REPRESENTASI IDENTITAS ANAK DALAM ANIMASI UPIN DAN IPIN MUSIM 10 EPISODE 11. JOM Fisip, 5(1), 1-15.

Herawati, Y. (2017). ISU GENDER PADA NOVEL KARYA PENGARANG KALIMANTAN TIMUR: SOSIAL, BUDAYA, DAN SEJARAH. Kandai, 10(2), 258-270. https://doi.org/10.26499/JK.V10I2.329

Islam, K. M. M., and Asadullah, M. N. (2018). Gender stereotypes and education: A comparative content analysis of Malaysian, Indonesian, Pakistani and Bangladeshi school textbooks. PLoS ONE, 13(1). https://doi.org/e0190807

Juliswara, V. (2014). Pendekatan Simulakra Terhadap Kekerasan Dalam Film Kartun Tom and Jerry. Jurnal Ilmu Komunikasi, 12(2), 150-162.

Karima, S., and Christin, M. (2015). Analisis Semiotika Charles Sanders Peirce Atas Presentasi Kekerasan dalam Serial Film Kartun Little Krishna. In eProceeding of Management (Vol. 2, hal. 2237).

Kirsh, S. J. (2006). Cartoon violence and aggression in youth. Aggression and Violent Behavior, 11(6), 547-557. https://doi.org/10.1016/J.AVB.2005.10.002

Lai, A., and Cooper, Y. (2016). Untangling Gender Divides Through Girly and Gendered Visual Culture. Journal of Social Theory in Art Education, 36(3).

Lavery, L. (2013). Gender Bias in the Media? An Examination of Local Television News Coverage of Male and Female House Candidates. Politics and Policy, 41(6), 877-910. https://doi.org/10.1111/polp.12051

Marecek, J., Kimmel, E. B., Crawford, M., and Hare-Mustin, R. T. (2003). Psychology of Women and Gender. In D. K. Freedheim and I. B. Weiner (Ed.), History of Psychology (Vol. 1, hal. 249). New Jersey: John Wiley and Sons Inc. https://doi.org/10.1002/0471264385

Marzuki. (n.d.). Kajian Awal Tentang Teori-Teori Gender. Yogyakarta.

Mustanzier, P. A. (2016). Penggunaan Gaya Bahasa Melayu dalam Tayangan Film Kartun Animasi Upin dan Ipin pada Perilaku Komunikasi Anak di Sd Negeri 1 Poasia Kendari. Jurnal Ilmu Komunikasi UHO, 1(2).

Nadzri, N. S. M., and Hassan, H. (2013). The Language Identities of Malaysians as Portrayed in Upin \& Ipin. Jurnal Teknologi (Social Sciences), 65(2), 109-114.

Peters, K. M., and Blumberg, F. C. (2002). Cartoon Violence: Is It as Detrimental to Preschoolers as We Think? Early Childhood Education Journal, 29(3), 143-148. https://doi.org/10.1023/A:1014576307194

Pri'ambudi, A. (2011). Representasi Pembelajaran Budi Pekerti dan Toleransi dalam Film Animasi Upin \& Ipin SEASON 1. Surakarta.

Purnomo, F. S. (2016). Analisis Nilai - Nilai Pendidikan Karakter Dalam Film Upin Dan Ipin Produksi Les Copaque Tahun 2010. DIKSA Jurnal Pendidikan Bahasa dan Sastra Indonesia, 2(2), 142-149.

Putri, Y. A. (2018). Analisis Semiotika Visual Animasi Upin \& Ipin Episode "Ikhlas Dari Hati." Padang.

Quinn, E. (2006). A Dictionary of Literary and Thematic Terms. (2nd, Ed.). New York: Facts On File. 
Rahmad. (2015). Nilai Pendidikan Islam Film Animasi Upin dan Ipin dalam Membentuk Perilaku Islami Anak di Kelurahan Tinanggea. Shautut Tarbiyah, 33(November), 91-111.

Rahminawati, N. (2001). Isu Kesetaraan Laki-Laki dan Perempuan (Bias Gender). Mimbar, 17(3), 273-283. https://doi.org/10.29313/mimbar.v17i3.48

Rosita, E. (2017). Ketidakadilan Gender dalam Dwilogi Padang Bulan dan Cinta di dalam Gelas Karya Andrea Hirata: Kritik Sastra Feminis. Kandai, 11(1), 6883. https://doi.org/10.26499/JK.V11I1.217

Sakina, A. I., and A, D. H. S. (2017). Menyoroti Budaya Patriarki Di Indonesia. Share: $\quad$ Social Work Journal, 7(1), 71. https://doi.org/10.24198/share.v7i1.13820

Saputro, M. E. (2011). Upin \& Ipin: Melayu Islam, Politik Kultur, dan Dekomodifikasi New Media. Kontekstualita, 26(1). Diambil dari https://s3.amazonaws.com/

Selden, R. (1985). A Reader's Guide to Contemporary Literary Theory. Sussex: The Harvester Press.

Sexton, M., Gervasoni, A., and Brandenburg, R. (2009). Australian primary mathematics classroom: APMC. Australian Primary Mathematics Classroom , 14(4). Diambil dari https://search.informit.com.au/

Sofia, A. S. (2003). Feminisme dan Sastra: Menguak Citra Perempuan dalam Layar Terkembang. Bandung: Katarsis.

Suryani, E. (2017). BATARI HYANG JANAPATI DALAM PERSPEKTIF GENDER. JENTERA: Jurnal Kajian Sastra, 6(2), 181-196. https://doi.org/10.26499/rnh.v6i2.177

Thompson, T. L., and Zerbinos, E. (1997). Television Cartoons: Do Children Notice It's a Boy's World? Sex Roles, 37(5/6), 415-432. https://doi.org/10.1023/A:1025657508010

Trier-Bieniek, A., and Leavy, P. (Ed.). (2014). Gender and Pop Culture. Rotterdam: Sense Publishers.

Ulya, C. (2016). Menakar Kualitas Struktur Dramatik Film Animasi Anak Adit dan Sopo Jarwo dalam Konteks Masyarakat Ekonomi Asean. In Konferensi Nasional Bahasa dan Sastra III (hal. 212-219). Surakarta: FKIP UNS. Diambil dari http://s3pbi.fkip.uns.ac.id/wpcontent/uploads/2016/01/Chafit-Ulya.pdf

Untari, M. F. A., and Purnomo, F. U. (2016). KAJIAN NILAI MORAL DALAM FILM KARTUN UPIN DAN IPIN EDISI "IKHLAS DARI HATI" PRODUKSI LES' COPAQUE. Malih Peddas, 6 (1), 9-18.

Zaduqisti, E. (2009). Stereotipe Peran Gender bagi Pendidikan Anak. Muwazah, l(1). 